\title{
Macrophage cytotoxicity towards isolated rat islet cells: neither lysis nor its protection by nicotinamide are Beta-cell specific
}

\author{
K.-D. Kröncke ${ }^{1}$, J.Funda ${ }^{1}$, B. Berschick ${ }^{2}$, H.Kolb ${ }^{2}$ and V.Kolb-Bachofen ${ }^{1}$ \\ Division of Immunobiology, Department of Medicine \\ ${ }^{2}$ Diabetes Research Institute, University of Düsseldorf, Düsseldorf, FRG
}

\begin{abstract}
Summary. In animal models of Type 1 (insulin-dependent) diabetes mellitus macrophages were shown to be the first immunocytes that infiltrate the pancreatic Langerhans islets in the autoimmune process. We now show direct macrophage cytotoxicity against isolated rat islet cells in an electron microscopical study, which permits investigation of the specificity of this process. Freshly isolated islet cells were co-incubated with syngeneic peritoneal macrophages at a target:effector-cell ratio of 1:2. After various time periods, the cells were directly fixed and embedded; the ratio of live and dead cells was evaluated by electron microscopy. Our results demonstrate that activated but not resident macrophages lyse islet cells in a time-dependent manner. After $15 \mathrm{~h}$ of co-incu-
\end{abstract}

bation lysis of islet cells is complete. No islet cell-macrophage contacts and no differences between the lysis of Beta cells or non-Beta cells were observed during the observation period. Islet cells encapsulated in alginate were also lysed by macrophages as a direct proof for soluble mediator(s) of cytotoxicity. Nicotinamide protected islet cells from lysis in a dosedependent manner. As a result of this electron microscopic study we conclude that even at very low target:effector ratios, activated macrophages lyse syngeneic islet cells regardless of islet cell type via secretion of humoral mediator(s).

Key words: Islet cell lysis, macrophage cytotoxicity, nicotinamide.
It has been shown that macrophages are the major infiltrating immunocytes in the early stages of insulitis in diabetes-prone BB rats $[1,2]$. Furthermore, administration of silica particles, which are selectively toxic to macrophages, results in the prevention of insulitis and diabetes in young BB rats [3]. A morphological study demonstrating macrophage cytotoxicity against islets and islet cell layer suggests a mechanism via direct cell-to-cell contacts between macrophages and islet cells [4]. Recently we showed that activated peritoneal macrophages lyse isolated ${ }^{3} \mathrm{H}$-leucine labelled syngeneic islet cells but not thyrocytes or hepatocytes [5].

Nicotinamide at high doses inhibits poly(ADP-ribose) synthetase activity [6,7], but may also scavenge hydroxyl free radicals $[8,9]$. Nicotinamide has been shown to prevent induction of diabetes by alloxan or streptozotocin $[10,11]$ in the rat and to improve the condition of partly depancreatized rats [12]. Furthermore, nicotinamide prevents or slows the manifestation of diabetes in non-obesediabetic (NOD) mice $[13,14]$.

This study describes the morphological results of in vitro experiments designed to distinguish between phagocytosis, lysis by direct cell-to-cell contact or without cell contact at a low target:effector-cell ratio (1:2). In addition, the Beta-cell specificity and the protective action of nicotinamide is analysed.

\section{Materials and methods}

Animals

Male and female Wistar and Lewis rats $(200 \mathrm{~g})$ from a local breeding source received a standard diet ("ssniff-R", Ssniff, Soest, FRG) and tap water ad libitum.

\section{Target and effector cells}

Islet cells and peritoneal macrophages were isolated as described previously [5]. Briefly, pancreatic islets were isolated by ductal injection of collagenase (Serva, Heidelberg, FRG, $0.32 \mathrm{U} / \mathrm{mg}, 3 \mathrm{mg} / \mathrm{ml}$ in Hank's buffered saline, HBSS) and subsequent centrifugation of the dispersed tissue on a Ficoll density gradient (Ficoll 400, Pharmacia, Freiburg, FRG). Whole islets were hand-picked and incubated for $10 \mathrm{~min}\left(37^{\circ} \mathrm{C} ; 5 \% \mathrm{CO}_{2}\right)$ in $\mathrm{Ca} / \mathrm{Mg}$-free HBSS with $3 \mathrm{mmol} / \mathrm{l} \mathrm{EGTA}$ (Merck, Darmstadt, FRG), $20 \mathrm{mg} / \mathrm{ml}$ bovine serum albumin, $11 \mathrm{mmol} / \mathrm{l}$ glucose and $2.5 \mathrm{mg} / \mathrm{ml}$ trypsin solution (Boehringer, Mannheim, FRG), final dilution $50 \mu \mathrm{l} / \mathrm{ml}$, and subsequently dissociated into single cells. The islet cell preparations contained less than $5 \%$ exocrine pancreatic cells or endothelial cells or fibroblasts.

Macrophages were activated in vivo by injection of $500 \mu \mathrm{l}$ heat inactivated Corynebacterium parvum suspension (Wellcome, Burgwedel, FRG) i.p. 5 days prior to isolation. Macrophages from peritoneal exudate were isolated by adherence to petri dishes pre-coated with fetal calf serum (FCS). Adherent cells were rigorously washed three times with $1 \mathrm{~h}$ culture period between washings. Adherent 

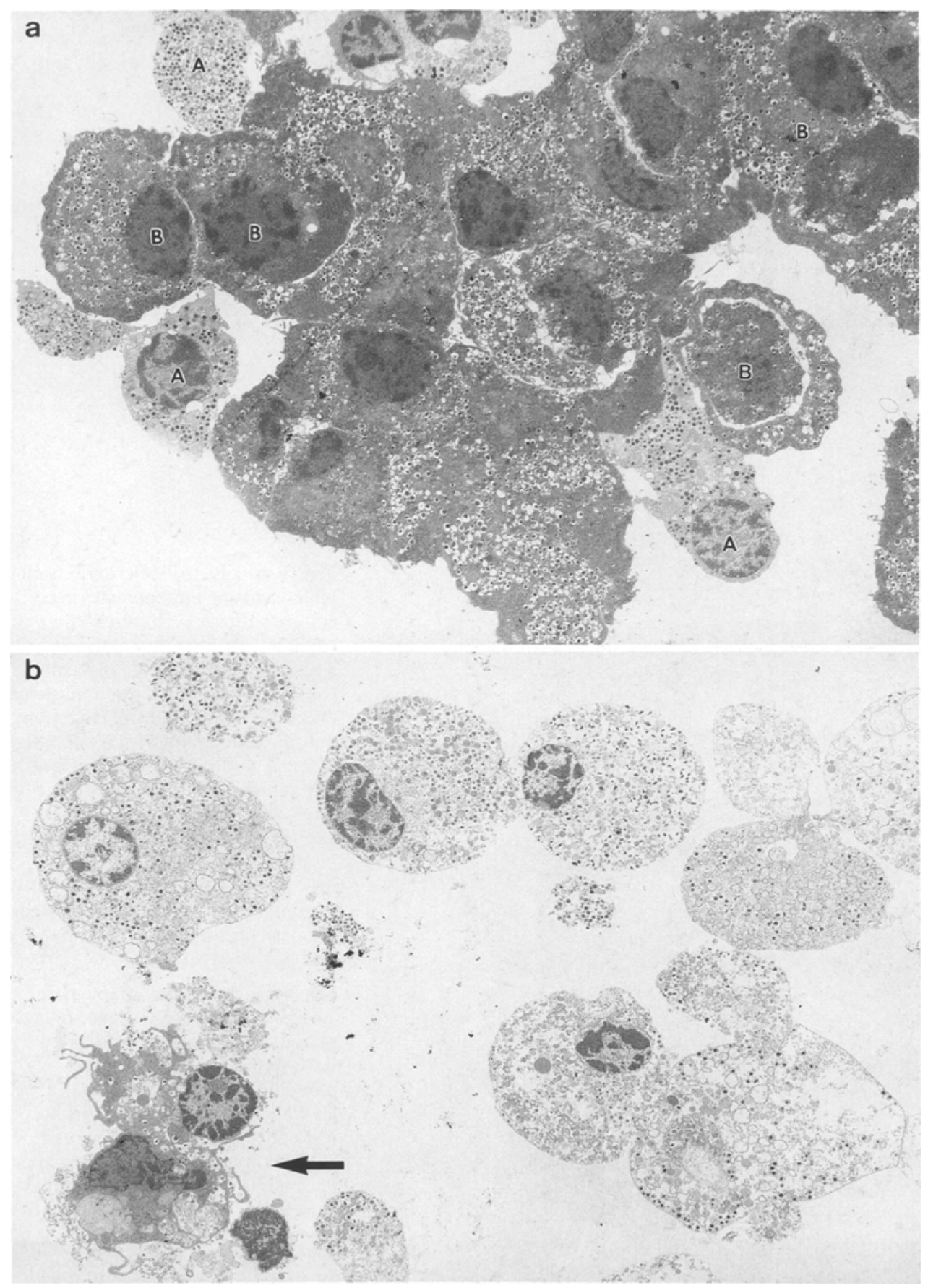

Fig. 1a, b. Low power electron micrographs of islet cells after $8 \mathrm{~h}$ of recovery culture and $15 \mathrm{~h}$ of culture in the absence (a) or presence (b) of activated macrophages. a Islet cells of control culture show rearrangement to pseudoislets with normal, well granulated cells ( $B$ Beta islet cells, $A$ Alpha islet cells). b Islet cells cultured as in a but in the presence of activated macrophages at a target:effector-cell ratio of $1: 2$. All islet cells are lysed. The arrow points to a macrophage engaged in Beta-islet cell debris uptake. Magnification: $3250 \times$ cells were harvested by incubation in $\mathrm{Ca} / \mathrm{Mg}$-free $\mathrm{HBSS}$ at $4^{\circ} \mathrm{C}$ for $5 \mathrm{~min}$. As judged by morphology, the resulting cell preparations consisted of $92 \%$ macrophages, $6 \%$ granulocytes, $1.5 \%$ mast cells and less than $0.5 \%$ Iymphocytes, which is in accordance with published cytochemistry results [5].

\section{Co-culture experiment with isolated islet cells}

About $5 \times 10^{4}$ target cells in $200 \mu \mathrm{l}$ were placed in sterile $1.5 \mathrm{ml}$ polypropylene micro sample tubes with $V$-shaped bottom that had been pre-coated with culture medium for $48 \mathrm{~h}$ at $37^{\circ} \mathrm{C}$. After $3-8 \mathrm{~h}$ of recovery culture, peritoneal macrophages were carefully added into the sample tubes with the pre-cultured islet cells to achieve a target:effector-cell ratio of 1:2 and a total volume of $600 \mu l$. The final co-culture was neither stirred nor centrifuged, but cells were allowed to settle. The cells were cultured in RPMI 1640 (Gibco, Heidelberg, FRG) supplemented with $25 \mathrm{mg} / \mathrm{l}$ ampicillin, $120 \mathrm{mg} / \mathrm{l}$ penicillin, $270 \mathrm{mg} / \mathrm{l}$ streptomycin (Serva), $1 \mathrm{mmol} / \mathrm{l}$ sodium pyruvate, $2 \mathrm{mmol} / \mathrm{l} \mathrm{L}-\mathrm{glu}$ tamine, $10 \mathrm{ml} / \mathrm{l}$ non-essential amino acids $\times 100(\mathrm{Gibco}), 23.8 \mathrm{mmol} / 1$ $\mathrm{NaHCO}_{3}, 10 \mathrm{mmo} / / \mathrm{HEPES}$ (Serva) and $10 \%$ heat inactivated FCS (Boehringer) for various intervals at $37^{\circ} \mathrm{C}$ in a humid atmosphere of $5 \% \mathrm{CO}_{2} / 95 \%$ air. Each experiment was performed between two and six times.

\section{Co-culture experiments with alginate-encapsulated islet cells}

Alginate, a linear polysaccharide composed of $\beta$-D-mannuronic and $\alpha$-L-guluronic acid, can be gelated by divalent cations and has been used to immobilize living cells [15].

About $5 \times 10^{4}$ islet cellswere cultured for $5 \mathrm{~h}$ in microsample tubes as described above. The culture medium was then reduced to $2-$ 

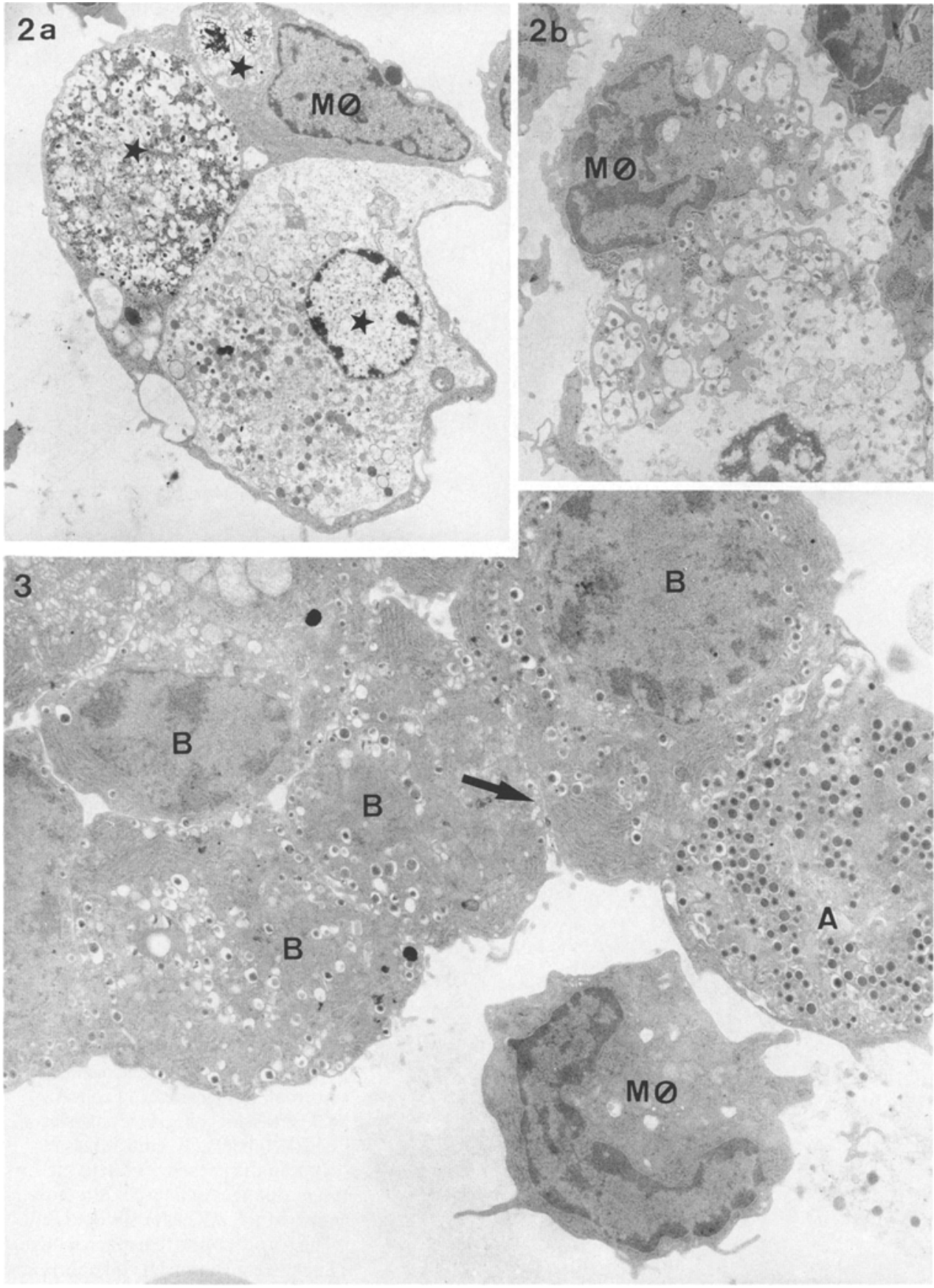

Fig. 2a, b. Electron micrographs of phagocytosing macrophages in coculture with islet cells after $3 \mathrm{~h}$ (a) or $8 \mathrm{~h}$ (b) recovery culture. a Phagocytosis of whole islet cells ( $\star$ ) by macrophages was a frequent event, if recovery culture lasted $3 \mathrm{~h}$ only and is indicative for recognition of trypsin-altered islet cell surface. b Extending islet cell recovery culture to $8 \mathrm{~h}$ prior to macrophage coculture, no phagocytosis of whole intact cells can be observed, but macrophages ( $m \phi)$ are engaged in the uptake of debris from previously lysed islet cells. Magnification: $8000 \times$

Fig. 3. Electron micrograph of cocultured cells in the presence of nicotinamide. Macrophage-mediated lysis of islet cells is completely prevented by the addition of $50 \mathrm{mmol} / \mathrm{l}$ nicotinamide. Morphology of islet cells is well preserved with normal stacks of rough endoplasmic reticulum (arrow) even in close contact with macrophages $(m \phi)$ ( $B$ Beta islet cell, $A$ Alpha islet cell). Magnification: $8400 \times$
$3 \mu \mathrm{l} \cdot 5 \mu \mathrm{l}$ of a degassed alginate stock solution ( $4 \%$ sodium alginate of low viscosity from Macrocystis pyrifera (Sigma, Deisenhofen, FRG) dissolved(weight/volume) in Ca/Mg-freeHBSScontaining $10 \mathrm{mmol} / \mathrm{l}$ HEPES) was added and the cells were carefully suspended. Then $2 \mu \mathrm{l}$ droplets of the cell suspension were added to $1 \mathrm{ml} \mathrm{HBSS}$ containing $10 \mathrm{mmol} / \mathrm{HEPES}$ and $50 \mathrm{mmol} / 1 \mathrm{CaCl}_{2}, \mathrm{pH} 7.3$, allowed to gelate for $10 \mathrm{~min}$ and then washed with $1 \mathrm{ml} \mathrm{RPMI} / 10 \% \mathrm{FCS}$. Single alginate beads containing $1-2 \times 10^{4}$ islet cells were incubated in $200 \mu \mathrm{l}$ $\mathrm{RPMI} / 10 \% \mathrm{FCS}$ for $2 \mathrm{~h}$ at $37^{\circ} \mathrm{C}$ for recovery from the entrapment procedure. Medium or activated macrophages were added to give a final volume of $400 \mu \mathrm{l}$. The cells were cultured for $15 \mathrm{~h}$ as described above.

\section{Electron microscopy}

Fixation, dehydration and embedding of the cells were all carried out in the micro sample tubes in which the cells had been cultured avoiding any centrifugation steps. The cells were fixed with ice-cold fixa- tion buffer ( $1 \%$ glutaraldehyde in $0.1 \mathrm{~mol} / 1$ cacodylate- $\mathrm{HCl}$ buffer, $0.1 \mathrm{~mol} / 1$ sucrose, and $2 \mathrm{mmol} / / \mathrm{CaCl}_{2}, \mathrm{pH}$ 7.2) for $10 \mathrm{~min}$, post-fixed with ice-cold $1.5 \% \mathrm{OsO}_{4}$ in the same buffer for $40 \mathrm{~min}$, dehydrated in a graded series of ethanol and embedded in epoxy resin [16]. The embedded specimen were processed for transmission electron microscopy as described earlier [17].

\section{Results}

\section{Morphology of the islet cells}

Islet cells were embedded either directly after isolation, following 3 or $8 \mathrm{~h}$ of recovery culture and an additional $15 \mathrm{~h}$ of culture in micro sample tubes. We found that under these culture conditions the islet cells re-associated in a time-dependent fashion and formed small cell aggregates 

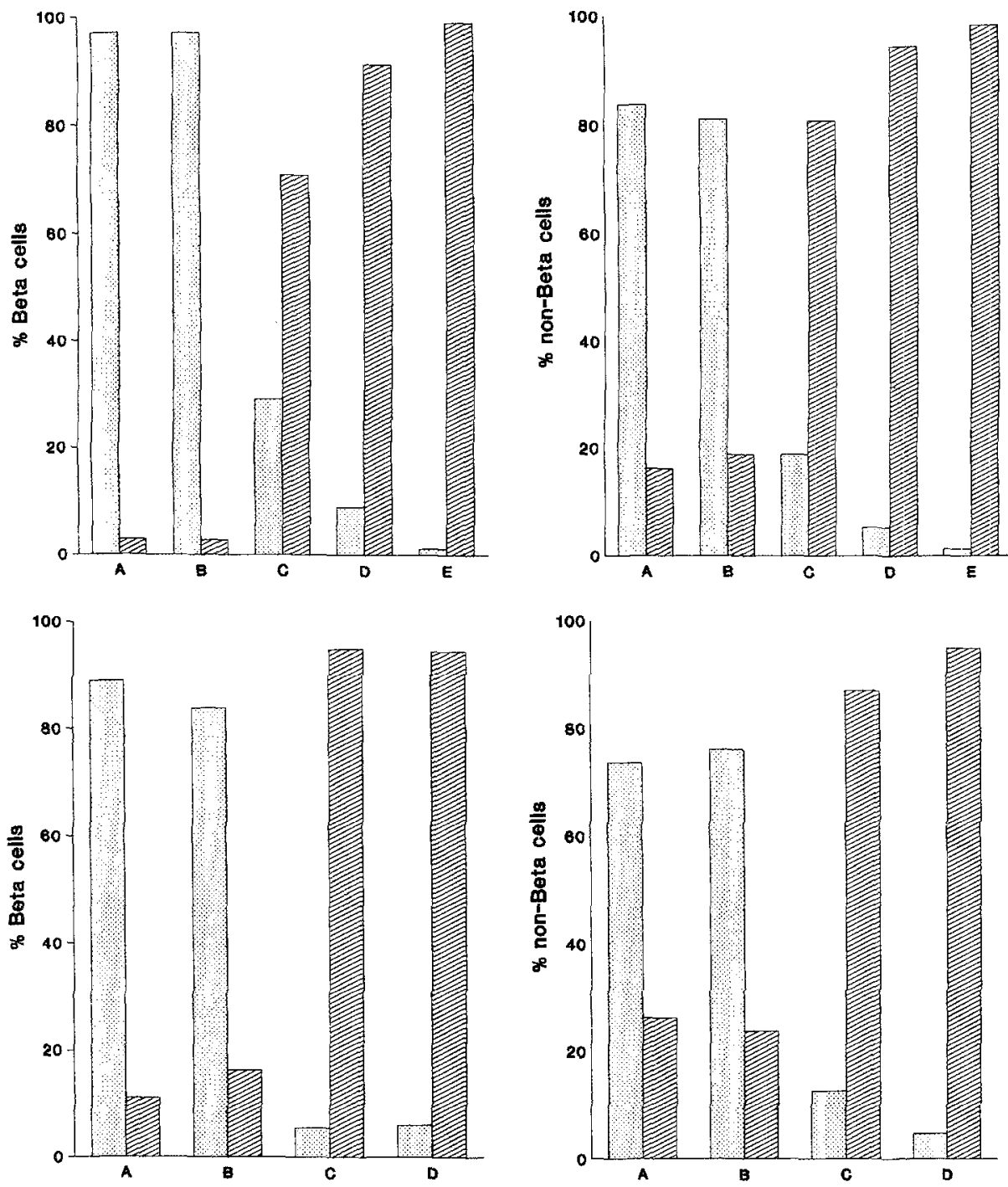

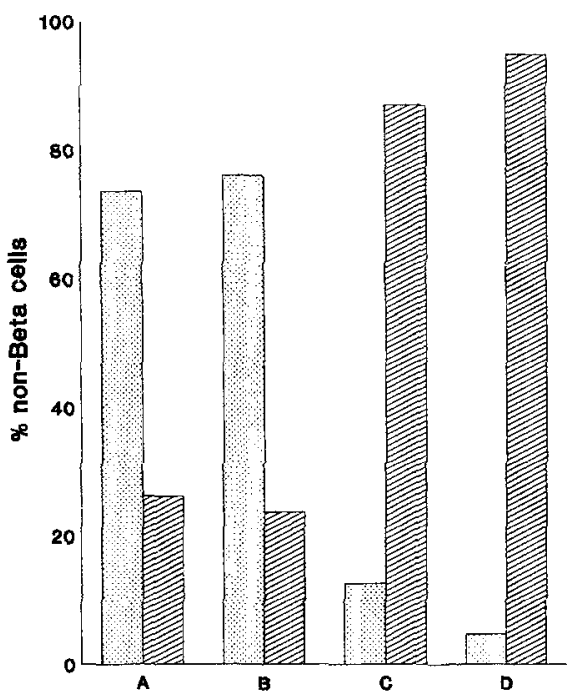

Fig.4. Quantitative determination of lysed vs intact Beta islet cells (left panel, $n=2575$ ) and non-Beta islet cells (right panel, $n=628$ ) after $8 \mathrm{~h}$ recovery culture and various times of co-incubation with activated macrophages (1:2) shows a time dependent lysis of both, Beta as well as nonBeta islet cells. Dotted bars: intact islet cells, hatched bars: lysed islet cells. ( $A$ : control incubation, $15 \mathrm{~h}$, no macrophages added $B: 4$ h co-incubation $C: 8$ h co-incubation $D: 12 \mathrm{~h}$ co-incubation $E: 15$ h co-incubation)

Fig.5. Quantitative determination of lysed vs intact Beta islet cells (left panel, $n=1814$ ) and non-Beta islet cells (right panel, $n=410$ ) after 8 h recovery culture and co-incubation with resident or activated macrophages $(1: 2)$ for $15 \mathrm{~h}$ in the presence of different glucose concentrations. ( $A$ : co-incubation with resident macrophages, $4 \mathrm{mmol} / \mathrm{l}$ glucose $B$ : co-incubation with resident macrophages, $11 \mathrm{mmol} / \mathrm{l}$ glucose $C$ : co-incubation with activated macrophages, $4 \mathrm{mmol} / 1$ glucose $D$ : co-incubation with activated macrophages, $11 \mathrm{mmol} / /$ glucose) with well preserved and well granulated endocrine cells. After about 24 h of culture, pseudoislets were formed with Alpha and Delta cells mostly located at the periphery (Fig. 1a). The cellular composition and the non-random distribution of Beta cells and non-Beta cells were similar to that found in pseudoislets received under different culture conditions $[18,19]$ and in intact islets $[20]$.

At the light microscopical level cell viability as determined by Trypan blue exclusion demonstrated that after 24 h of culture under the conditions used for the electron microscopical studies more than $90 \%$ of the islet cells were intact, most of them re-arranged to cell-clusters.

On the electron microscopical level it was found that after $24 \mathrm{~h}$ of culture more than $95 \%$ of the Beta cells and about $70-80 \%$ of the non-Beta cells were intact.

\section{Co culture of islet cells with macrophages}

After co-culturing islet cells and activated macrophages in close proximity at the bottom of micro sample tubes, three different effects could be defined: a) lysis of islet cells, b) phagocytosis of previously lysed islet cells and c) phagocytosis of intact islet cells. Lysis of islet cells is characterized by disrupted plasma membranes concomitant with low electron density of the cytoplasm, swollen mitochondria, vesiculated rough endoplasmatic reticulum and pycnotic nuclei (Fig. 1b). Phagocytosis of previously lysed or intact cells could clearly be distinguished: after phagocytosis of previously lysed cells debris was found in many separate macrophage vacuoles, while after phagocytosis of whole islet cells these were found within one macrophage vacuole (Fig. 2a, b).

When islet cells were co-incubated with activated macrophages after $3 \mathrm{~h}$ of recovery culture following isolation, many intact islet cells were phagocytosed by the activated macrophages. Prolonging the recovery culture to $8 \mathrm{~h}$ (when islet cell aggregates could already be detected), less than $0.5 \%$ of the islet cells were phagocytosed as intact cells. This was taken as an indication that a $3 \mathrm{~h}$ recovery period was not sufficient for islet cells to repair trypsin-induced alterations. Macrophages apparently recognize the altered-self and phagocytoe these cells. After a prolonged recovery period minimal phagocytosis was interpreted as an indicator of complete islet cell surface repair. Therefore, a recovery culture of $8 \mathrm{~h}$ was taken as standard condition.

\section{Time-dependent lysis of islet cells by activated macrophages}

Islet cells and peritoneal macrophages which had been activated in vivo by application of heat-inactivated Corynebacterium parvum were co-cultured for $4,8,12$ and 


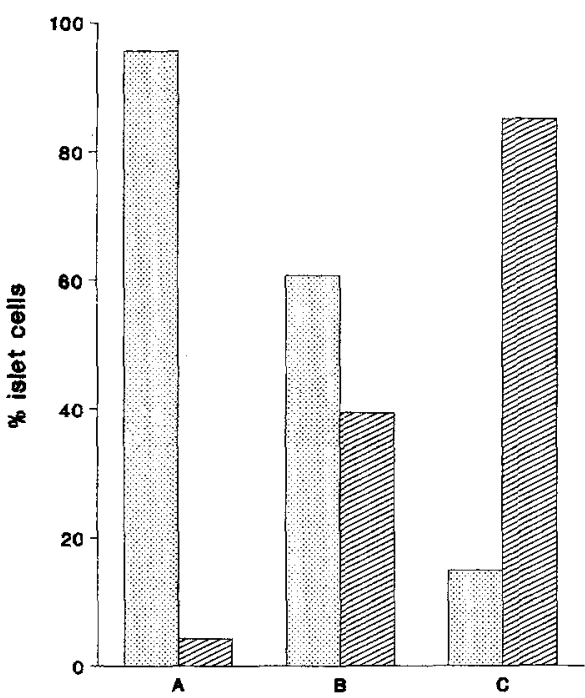

Fig. 6. Quantitative determination of lysed vs intact islet cells $(n=2633)$ entrapped within alginate beads after $5 \mathrm{~h}$ recovery culture. Encapsulated islet cells were again cultured for $3 \mathrm{~h}$, and then co-incubated for $15 \mathrm{~h}$ with activated macrophages at different target:effector-cell ratios for $15 \mathrm{~h}$. (A: control incubation without macrophages $B$ : co-incubation with activated macrophages (1:2) $C:$ coincubation with activated macrophages $(1: 10)$ )
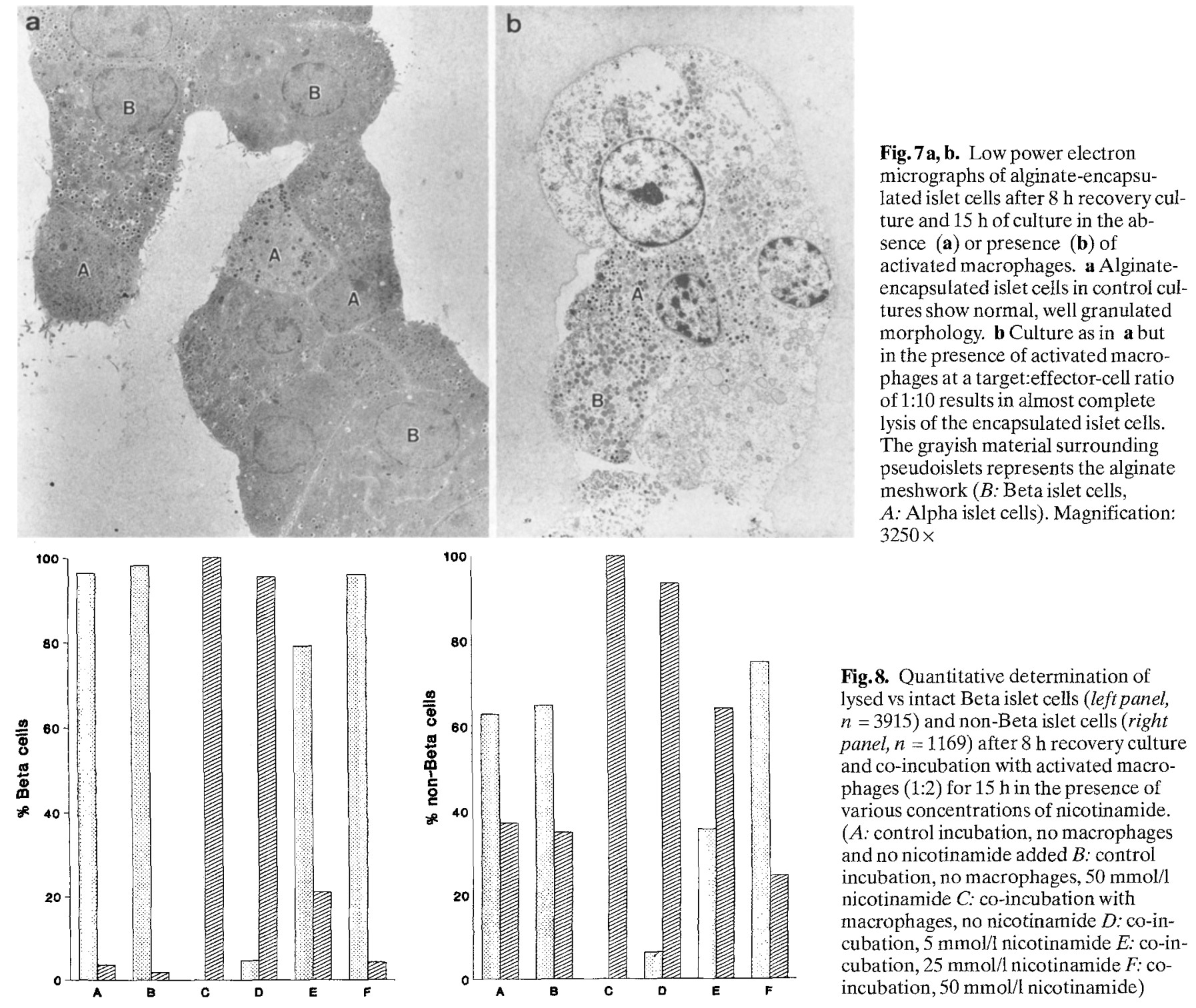

$15 \mathrm{~h}$, respectively, in the presence of $11 \mathrm{mmol} / \mathrm{l}$ glucose. Parallel islet cells were cultured under the same conditions without macrophages as control. Figure 4 shows that co-culturing islet cells and activated macrophages resulted in a time-dependent lysis of both Beta and nonBeta cells. While almost all islet cells are intact after $4 \mathrm{~h}$ of co-incubation, only $20-30 \%$ of the islet cells were morphologically intact after $8 \mathrm{~h}$ of co-culture. After $15 \mathrm{~h}$ target cell lysis was complete (Fig. 1b). No predominance of Beta or non-Beta cell lysis, no cell-to-cell contacts between macrophages and intact islet cells and no significant phagocytosis of intact target cells could be detected in any of the co-culture periods investigated.

\section{Co-culture of islet cells with resident or activated macrophages}

To investigate the influence of islet cell stimulation by glucose and the activation status of the macrophages on target-cell lysis, islet cells were co-incubated with resident and activated macrophages, respectively, in the presence of 4 and $11 \mathrm{mmol} / \mathrm{l}$ glucose. Figure 5 shows that after $15 \mathrm{~h}$ of co-incubation with resident macrophages, more than 
$80 \%$ of the Beta cells and more than $70 \%$ of the non-Beta cells remained intact while in the same time more than $90 \%$ of the islet cells were lysed by activated macrophages. No difference between the experiments with 4 and $11 \mathrm{mmol} / 1$ glucose could be found. Similar results were observed with both Wistar and Lewis rats.

\section{Co-culture of alginate-encapsulated islet cells with activated macrophages}

To exclude direct cell-to-cell contacts between macrophages and islet cells and to investigate whether microencapsulation of islet cells protects from macrophage-mediated killing, the targets were encapsulated in small alginate beads. The entrapped islet cells cultured in the absence of macrophages were well preserved and well granulated. The cellular composition and the non-random distribution of Beta cells and non-Beta cells were the same as found in the experiments described above. About $95 \%$ of the islet cells were intact after 15 h of culture (Figs. 6 and $7 \mathrm{a}$ ). No islet cells outside the alginate beads could be detected, indicating, that the beads were stable during the incubation and embedding procedure. Co-incubation of the encapsulated islet cells with activated macrophages for $15 \mathrm{~h}$ at a target:effector-cell ratio of $1: 2$ resulted in lysis of about $40 \%$ of the islet cells (Fig. 6). When the target:effector-cell ratio was raised to $1: 10$, almost complete lysis was evident after $15 \mathrm{~h}$ of co-culture (Fig. 6). Cell lysis of alginate encapsulated and non-encapsulated islet cells was indistinguishable by morphology (Fig. 7b). No macrophages could be detected inside the alginate beads nor were they found adhering to the bead surface. Encapsulation of activated macrophages and subsequent co-incubation with isolated islet cells also resulted in lysis of target cells (data not shown).

\section{Protective effect of nicotinamide}

To investigate if nicotinamide protects islet cells from lysis by activated macrophages, the co-culture experiments were done in the presence of various concentrations of nicotinamide. Figure 8 shows that $5 \mathrm{mmol} / 1$ nicotinamide did not protect islet cells from lysis by activated macrophages, while in the presence of $25 \mathrm{mmol} / \mathrm{l}$ nicotinamide, most Beta cells $(79.0 \%)$ and many non-Beta cells $(35.7 \%)$ remained intact. $50 \mathrm{mmol} / \mathrm{l}$ nicotinamide results in almost complete protection of the target. In the presence of $50 \mathrm{mmol} / \mathrm{l}$ nicotinamide both activated macrophages and islet cells were morphologically indistinguishable from controls (Fig. 3). No islet cell-macrophage contacts were present in these experiments. Pre-incubation of activated macrophages with $50 \mathrm{mmol} / \mathrm{l}$ nicotinamide for $1 \mathrm{~h}$ and subsequent co-culture in the absence of nicotinamide did not protect islet cells (data not shown). Similar results were observed with both Wistar and Lewis rats.

\section{Discussion}

We recently reported that activated macrophages spontaneously lyse pancreatic islet cells [5]. In these experiments the islet cells were incubated with radioactive ${ }^{3} \mathrm{H}$-leucine prior to co-culture with macrophages. This experimental setup does not permit distinction between Beta and nonBeta islet cells and uses a high target:effector-cell ratio of $1: 20-40$ which is necessary to detect significant radioactive label release.

We now have developed an experimental setup with a low target:effector-cell ratio (1:2) examining the cells after co-culture experiments by electron microscopy. The main difference to the procedure described before [5] is, that islet cells and macrophages are now forced into comparatively close, "tissue-like", proximity by the V-shaped bottom of the sample tubes. This appears to allow for efficient diffusion of mediator(s) to target cells compared to flatbottom well incubation with comparatively long diffusion distances.

The results obtained clearly show that co-incubation of activated macrophages with isolated islet cells results in a time-dependent lysis of the target cells. No differences in the sensitivity of Beta or non-Beta cells against macrophage-mediated lysis could be detected. However, it should be noted that non-Beta cells, which are mostly located at the periphery of the pseudoislets, are more sensitive to the isolation procedure and the culture conditions than the Beta cells. This in vitro situation is the reverse of the in vivo situation, where soluble mediators transported via blood would reach Beta cells first, due to the direction of blood supply [21].

In all experiments a basic finding was that no cell-tocell contacts between activated macrophages and intact islet cells were formed. This indicates that macrophage cytotoxicity does not require cell-to-cell contacts with islet cells but is mediated by one or several secreted macrophage products. This finding is reminiscent of macrophage cytotoxicity towards murine P815 mastocytoma cells $[22,23]$.

Direct proof for the cytolytic action of (a) humoral macrophage product(s) was provided by the encapsulation experiments, where both encapsulation of either targets or effectors invariably resulted in islet cell lysis. These experiments show that the toxic agent(s) can diffuse over a comparatively large distance (up to $700 \mu \mathrm{m}$ to the interior of the alignate bead) but that under these conditions higher concentrations of the cytolytic product(s) are required for complete lysis as reflected by the need for a higher target:effector ratio.

The macrophage product interleukin- 1 has been shown to exert a cytolytic effect on islets when administered for up to 6 days [24]. The combination of interleukin- 1 and tumour necrosis factor was found to synergistically affect isolated islet cells after co-incubation for 4 days [25]. However, islets treated with interleukin-1 showed reduced glucose-induced insulin secretion, but were morphologically intact and regained their ability to secrete insulin after the removal of interleukin-1 [26]. We show here that diffusible macrophage product(s) mediate rapid islet cell killing within $15 \mathrm{~h}$. Due to the fast action found here other cytolytic secretory products of macrophages such as reactive nitrogen or oxygen intermediates and neutral proteases [27] may be responsible for islet cell lysis.

This was further supported by the finding that high concentrations of nicotinamide, which are not toxic to 
islet cells or macrophages, completely prevented both Beta and non-Beta cells from lysis by activated macrophages. Earlier experiments with nicotinamide in co-cultures of macrophages and radiolabelled islet cells have also shown protective effects [28]. It has been shown that high doses of nicotinamide scavenge hydroxyl free radicals [8]. It was also found that nicotinamide prevents DNA single-strand breaks in rat insulinoma cells when cultured in the presence of alloxan [9], but when cultured in the presence of streptozotocin, nicotinamide increased DNA single-strand breaks in the same cells indicative of inhibition of the poly(ADP-ribose) synthetase [9]. With the data obtained in our experiments we cannot distinguish which of these nicotinamide effects exerts the protection from lysis. However, the long distance of action found in the encapsulation experiments are not in favour of short-lived radicals as the main active product. We conclude that macrophage cytotoxicity towards islet cells in vitro is not Beta-cell specific, is mediated by soluble factor(s) and is counteracted by nicotinamide.

Acknowledgements. We thank Ms. A. Schlömer for expert technical assistance, Ms. S. Wenzel-Unger and Ms. M. Turken for processing of micrographs and Ms. I. Werner for manuscript typing. This work was supported by a grant from the Deutsche Forschungsgemeinschaft (Ko 806/2-2 to V.K.-B.) and by the Bundesministerium für Jugend, Familie und Gesundheit and the Ministerium für Wissenschaft und Forschung des Landes Nordrhein-Westfalen.

\section{References}

1. Lee KU, Kim MK, Amano K, Pak CY, Jaworski MA, Mehta JG, Yoon JW (1988) Preferential infiltration of macrophages during early stages of insulitis in diabetes-prone BB rats. Diabetes 37 : $1053-1058$

2. Hanenberg H, Kolb-Bachofen V, Kantwerk-Funke G, Kolb H (1989) Macrophage infiltration precedes and is prerequisite for lymphocytic insulitis of pre-diabetic BB rats. Diabetologia 32: 126-134

3. Oschilewski M, Kiesel U, Kolb H (1986) Administration of silica prevents diabetes in BB-rats. Diabetes 34: 197-199

4. Schwizer RW, Leiter EH, Evans R (1984) Macrophage-mediated cytotoxicity against cultured pancreatic islet cells. Transplantation 37: 539-544

5. Appels B, Burkart V, Kantwerk-Funke G, Funda J, KolbBachofen V, Kolb H (1989) Spontaneous cytotoxicity of macrophages against pancreatic islet cells. J Immunol 142: 3803-3808

6. Preiss J, Schlaeger R, Hilz H (1971) Specific inhibition of poly ADP ribose polymerase by thymidine and nicotinamide in HeLa cells. FEBS Lett 19: 244-246

7. Colyer RA, Burdette KE, Kidwell WR (1973) Poly ADP-ribose synthesis and DNA replication in synchronized mouse L-cells. Biochem Biophys Res Commun 53: 960-966

8. Wilson GL, Patton NJ, McCord JM, Mullins DW, Mossman BT (1984) Mechanisms of streptozotocin- and alloxan-induced damage in rat B cells. Diabetologia 27:587-591

9. LeDoux SP, Hall CR, Forbes PM, Patton NJ, Wilson GL (1988) Mechanisms of nicotinamide and thymidine protection from alloxan and streptozocin toxicity. Diabetes 37: 1015-1019

10. Lazarow A, Liambies J, Tausch AJ (1950) Protection against diabetes with nicotinamide. J Lab Med 36: 249-258

11. Stauffacher W, Burr I, Gutzeit A, Beaven D, Veleminsky J, Renold AE (1970) Streptozotocin diabetes: time course of irre- versible B-cell damage; further observations on prevention by nicotinamide. Proc Soc Exp Biol Med 133: 194-200

12. Yonemura $\mathrm{Y}$, Takashima T, Niwa K, Miyazaki I, Yamamoto $H$ (1984) Amelioration of diabetes mellitus in partially depancreatized rats by poly(ADP-ribose) synthetase inhibitors. Diabetes 33: 401-404

13. Yamada K, Nonaka K, Hanafusa T, Miyazaki A, Toyoshima $H$, Tarui S (1982) Preventive and therapeutic effects of large-dose nicotinamide injections on diabetes associated with insulitis. An observation in nonobese diabetic (NOD) mice. Diabetes 31: $749-753$

14. Nakajima H, Fujino-Kurihara H, Hanafusa T et al. (1985) Nicotinamide prevents the development of cyclophosphamide-induced diabetes mellitus in male non-obese diabetic (NOD) mice. Biomed Res 6: 185-189

15. Smidsrød O, Skjåk-Bræk G (1990) Alginate as immobilization matrix for cells. Trends Biotechnol 8: 71-78

16. Spurr AR (1969) A low-viscosity epoxy resin embedding medium for electron microscopy. J Ultrastruct Res 26: 31-43

17. Kolb-Bachofen V, Epstein S, Kiesel U, Kolb H (1988) Low dose streptozocin-induced diabetes in mice. Electron microscopy reveals single-cell insulitis before diabetes onset. Diabetes 37: $21-27$

18. Takaki R, Ono J, Fukuma M, Ikegami T (1975) Long-term culture of isolated pancreatic islet cells. Proc Soc Exp Biol Med 149: $402-406$

19. Montesano R, Mouron P, Amherdt M, Orci L (1983) Collagen matrix promotes reorganization of pancreatic endocrine cell monolayers into islet-like organoids. J Cell Biol 97:935-939

20. Orci L (1982) Macro- and micro-domains in the endocrine pancreas. Diabetes 31:538-565

21. Samols E, Stagner JI, Ewart RBL, Marks V (1988) The order of islet microvascular cellular perfusion is $B \rightarrow A \rightarrow D$ in the perfused rat pancreas. J Clin Invest 82: 350-353

22. Keller R, Keist R, Groscurth P (1986) Firm persistent binding between activated macrophages and tumor cells is not a prerequisite for the mediation of cytolysis. Int J Cancer 37: 89-95

23. Lu CY, Lombardi MJ, Shea CM, Dustin LB (1988) High strength binding of P815 mastocytoma cells is not necessary for their lysis by macrophages which have been primed and triggered in vitro. J Immunol 141: 1083-1090

24. Mandrup-Poulsen T, Bendtzen K, Nerup J, Dinarello CA, Svenson M, Nielsen JH (1986) Affinity-purified human interleukin 1 is cytotoxic to isolated islets of Langerhans. Diabetologia 29: 63-67

25. Pukel C, Baquerizo H, Rabinovitch A (1988) Destruction of rat islet cell monolayers by cytokines. Synergistic interactions of interferon- $\gamma$, tumor necrosis factor, lymphotoxin, and interleukin 1 . Diabetes 37: 133-136

26. Comens PG, Wolf BA, Unanue ER, Lacy PE, McDaniel ML (1987) Interleukin 1 is potent modulator of insulin secretion from isolated rat islet of Langerhans. Diabetes 36: 963-970

27. Nathan CF (1987) Secretory products of macrophages. J Clin Invest 79:319-326

28. Kolb H, Burkart V, Appels B, Hanenberg H, Kantwerk-Funke G, Kiesel U, Funda J, Schraermeyer U, Kolb-Bachofen V (1990) Essential contribution of macrophages to islet cell destruction in vivo and in vitro. J Autoimmun 3: 117-120

Received: 24 September 1990

and in revised form: 13 December 1990

Dr. V. Kolb-Bachofen

Division of Immunobiology

Department of Medicine

University of Diisseldorf

Moorenstrasse 5

W-4000 Düsseldorf 1

FRG 